\title{
THE EFFECTS OF ORGANIZATIONAL CULTURE, WORK COMMITMENT, AND COMPETENCE ON EMPLOYEE SATISFACTION AND PERFORMANCE IN PT BANK RAKYAT INDONESIA (PERSERO) TBK
}

\author{
Wagiman S. ${ }^{*}$, Budiyanto, Suwitho \\ Sekolah Tinggi IImu Ekonomi Indonesia (STIESIA), Surabaya, Indonesia \\ *E-mail: wagiman.gw@gmail.com
}

\begin{abstract}
The role of human resources in banking companies is the most important because the existence of human resources will affect the smoothness of bank activities in achieving the goals. The populations of this research were employees who had working period above 2 years at PT Bank Rakyat Indonesia (Persero) Tbk. The data collection method used in this research came from the results of questionnaires that were distributed to the respondents. Previous researchers applied multiple linear regression analysis whereas the research conducted by the researchers applied path analysis with Structural Model Equation approach through the application of Smart Partial Least Square (SEM PLS 2.0).
\end{abstract}

\section{KEY WORDS}

Organizational culture, work commitment, employee, satisfaction.

The role of human resources in banking companies is the most essential part because the human resources will affect the smoothness of bank activities in achieving its goals. Thus, it needs to be supported by human resources which will improve employee performance. Bintoro and Daryanto (2017: 1) argued that the employee performace is the quality and quantity of work achieved by an employee in performing their duties in accordance with their responsibilities.

The phenomenon, related to employee performance, has been done through the annual appraisal mechanism for employee performance using Performance Management System (PMS) or in common language what so-called Key Performance Indicators (KPI) in PT Bank Rakyat Indonesia (Persero) Tbk, Regional Office of Semarang. This assessment system is not only used to measure employee performance but also to measure the target achievement of employee work.

The issues of employee performance within the scope of banking relate to the success of a bank in achieving its goals. Sinambela (2012) mentioned that the performance can be optimized through the determination of salary, employee selection, goal orientation, training and development, description of organizational planning and description of responsibilities. Next, Zubair and Chair (2015) stated that the factors affecting employee performance are the organizational culture, leadership, organizational commitment and job satisfaction. Furthermore, Supiyanto (2015) said that performance can be improved with leadership, competence, organizational commitment and job satisfaction. However, not all of the above variables will be researched. The researchers limit only on the variables of organizational culture, work commitment and competence.

Employee performance is the most essential part and plays an important role in achieving the goals of a bank. One of the factors affecting employee performance is job satisfaction. According to Luthans (2012: 243), job satisfaction is the result of employee's perceptions of how well their work is in delivering what is considered to be important. The correlation of job satisfaction and employee performance has an effect which is in accordance with the opinion put forward by Robbins and Judge (2015: 52) who mentioned that the correlation of job satisfaction and employee performance is a myth. On the contrary, the review of 300 studies stated that the correlation is strong enough, so the opinions put forward by Robbins and Judge stated that there was a strong correlation between job satisfaction and employee performance. 
In terms of employee satisfaction and performance relations, according to Wibowo (2013: 141), job satisfaction had a moderate positive effect on performance. People who have higher level of job satisfaction tend to have higher level of performance, higher level of citizenship behavior and lower level of counter-productive behavior. Supiyanto (2015) examined the effect of leadership, competence and organizational commitment to employee performance mediated by job satisfaction. The findings showed that compensation, competence and organizational commitment have a significant effect on employee performance and job satisfaction does not have a significant effect on employee performance. Meanwhile, Mardiani and Dewi (2015) found that job satisfaction and organizational commitment have a positive and significant effect on the employee performance of a bank in South Borneo either simultaneously or partially.

Meanwhile, Javed (2014) found that there is a positive and significant correlation of employee empowerment, work environment, job loyalty, and job satisfaction on employee performance. Meanwhile, Vrinda and Jacob (2015) found that employees would be more satisfied if they got what they expected so that it would affect employee performance. Similarly, Inuwa's research (2015) found that there is a positive effect between job satisfaction, work attitude and equity on the employee performance in an organization. Based on previous research, there is a research gap in which there is a difference between the findings of previous research; some found significant effect and some found no significant effect, so this becomes the research gap from this research.

Organizational culture is a system of shared meanings adopted by the members of the organization in which it differentiates the organization from other organizations. This system of shared meanings is a set of key characteristics upheld by the organization (Sunyoto, 2012: 225). Based on the opinion expressed by Sunyoto, it can be said that organizational culture for the company is a factor that plays an important role in increasing employee job satisfaction. It was stated by Koesmono (2005), in which the findings of his research found that organizational culture affects job satisfaction and employee performance. Widagdo's research (2013) found that organizational culture and organizational commitment affect job satisfaction.

Research conducted by Rohayati (2013) showed that partially organizational culture, leadership style and work motivation do not have significant effect on job satisfaction. Then, the research findings of Sabri et al. (2011) found that organizational culture is categorized into two components: organizational culture related to manager and leader (OCM) and organizational culture related to employee (OCE). In this case, the effect of studies of both types of culture on job satisfaction is positive and significant. There is a research gap because the findings are inconsistent among those research findings, so it is still necessary to conduct a research in this case.

Moreover, the effect of organizational culture on employee performance, according to Suzanto and Solihin (2012), showed that organizational culture, interpersonal commitment and organizational commitment have a positive and significant effect on employee performance. Meanwhile, Soedjono (2005) found that organizational culture affects the organizational behavior and employee performance. Meanwhile, Wanjiku and Agusioma (2014) found that organizational culture has an effect on employee performance. Based on previous research, there are inconsistent research findings in which some previous research found significant effect and some others found no significant effect. Therefore, this is the research gap of this research.

Organizational commitment is related to the strength of one's introduction and involvement in a particular organization (Panggabean, 2011: 137), so it can be concluded that organizational commitment affects job satisfaction. The findings of a research conducted by Arifah and Romadhon (2015) showed that organizational commitment has an effect on job satisfaction with positive regression coefficient direction. The findings of a research conducted by Sunarno and Liana (2015) found that organizational commitment was not proven to affect employee performance. Meanwhile, Adekola research findings (2012) indicated that there is significant effect between organizational commitment and employee job satisfaction. 
Based on the previous researches, there are inconsistent research findings in terms of the effect of organizational commitment to job satisfaction. It is because some researchers found significant effect and some others found insignificant effect. In terms of organizational commitment to employee performance, Gunawan (2015) found that organizational commitment and locus of control have a significant effect on employee performance. Widi (2015) found that there is no significant effect between organizational commitment and employee performance. Furthermore Putrayana (2016) found that organizational commitment has a negative effect on employee performance. In addition, Giri et al. (2016) found that organizational commitment significantly affects employee performance.

Based on the findings of previous researches, there is a research gap in which some previous researches found positive and significant effect and some others found significant but negative effect. Next, competence in an organization is the most essential part. According to Sudarmanto (2010: 96), this competence is associated with a desire to work well or meet/ exceed the performance standards or the urge to work properly.

Edison et al. (2016: 142) mentioned that competence is related to the ability of individuals who perform a job properly and have an advantage based on the matters of knowledge, skill, and attitude. Employee competence plays an important role because competence will affect job satisfaction and employee performance. It is based on a research conducted by Bagia (2015) who suggested that competence affects job satisfaction. Meanwhile, a research conducted by Zainuddin et al. (2015) found that competence has an effect on job satisfaction and employee performance. Murgianto et al. (2016) showed that commitment, competence, and job satisfaction have a significant effect on work motivation. Meanwhile, commitment, competence, and job satisfaction have a significant effect on employee performance at Integrated Service Office in East Java.

Moreover, the research findings of Arifin (2012) showed that competence and organizational culture have a positive and significant effect on job satisfaction. Similarly, Dhermawan et al. (2012) found that competence has no significant effect on employee performance.

The research findings on the effect of competence on job satisfaction and employee performance contain research gap because some previous researches found significant effect on job satisfaction and employee performance and some others found that there is no significant effect.

Based on the background of the research that has been described previously, the formulation of the research problem becomes the following:

1) Does organizational culture affect employee job satisfaction?

2) Does work commitment affect employee job satisfaction?

3) Does competence affect employee job satisfaction?

4) Does the organizational culture affect employee performance?

5) Does work commitment affect employee performance?

6) Does competence affect employee performance?

7) Does job satisfaction affect employee performance?

The objectives of this research are to test the effect of:

1) Organizational culture on employee job satisfaction

2) Work commitment on employee job satisfaction

3) Competence on employee job satisfaction

4) Organizational culture on employee performance

5) Work commitment on employee performance

6) Competence on employee performance

7) Job satisfaction on employee performance

\section{METHODS OF RESEARCH}

The research design used by researchers emphasized quantitative research. Indrawan and Yaniawati (2014: 51) argued that quantitative approach is a form of scientific research that examines one problem of one phenomenon and sees the possibility of linkage or 
relationships between variables in the issues. This research was designed to examine the effect of organizational culture, work commitment and competence on employee performance mediated by job satisfaction.

Population and Sample. Populations of this research were permanent employee with working period over 2 years at PT Bank Rakyat Indonesia (Persero) Tbk, Regional Office of Semarang as many as 871 people from 22 branches and 1 region. The samples used in this research were 274 respondents. In addition, the determination of research samples proportionally was performed by using random sampling technique.

Research Setting. This research was conducted at PT Bank Rakyat Indonesia (Persero) Tbk, Regional Office of Semarang. The reasons for choosing PT. Bank Rakyat Indonesia (Persero) Tbk, Regional Office of Semarang were under the consideration that there was a correction to the performance and research gap. Moreover, the bank was one of the largest state-owned banks. In addition, it facilitated the researchers in obtaining and collecting the available data required for this research. The time required for the completion of this dissertation was from March to May of 2017.

The Procedure of Data Collection. The data collection method used in this research was through the results of distributing the questionnaires to the respondents. The results of the questionnaire distribution were the procedure that lifted the variables under the research such as organizational culture, organizational commitment, competence, job satisfaction, and employee performance. The data collection of this research was addressed to 274 employees in 23 offices (22 branch offices and 1 regional office) in the work area of PT BRI, Regional Office of Semarang.

Analysis Using Structural Equation Model of Partial Least Square (SEM-PLS). SEM application used in this research was variant-based SEM with statistical technique of SEMPLS (Partial Least Square). The researchers' reason in using SEM-PLS was because after applying variant-based SEM test using Software Amos, it showed that multivariate normality was 47,62. Santoso (2013) in Bahri and Zamzam (2014: 28) argued that if the critical ratio (CR) skewness or CR kurtosis lies between -2.58 to +2.58 , it is considered to be normally distributed. In this case, the multivariate normality was $47.62>2.58$, so it could be said that the data were not normally distributed. Therefore, this research would be more feasible to use SEM-PLS because it does not require normal distributed data. The findings of this research aimed to perform hypothesis testing by using SEM-Partial Least Square (PLS) analysis model. This research was conducted by using 2 models of approach consisting of measurement model (outer model) and structural model (inner model).

Analysis of Measurement Model (Outer Model). The analysis of measurement model (outer model) aimed to measure the validity and reliability of the model through the Algorithm process in SEM-PLS 2.0. The outer model included the validity test (convergence validity and discrimination validity) in which the reliability test (composite reliability and cronbach's alpha) with R2 value was a measuring instrument in measuring the accuracy of the research model. It can be described as the following: Construct Validity Test; Construct Reliability Test.

Analysis of Structural Model (Inner Model). The structural model was evaluated by using $\mathrm{R}$ square for the dependent construct. Stone-Geisser $\mathrm{Q}$ square test was used for predictive relevance and t-test as well as the significance of the structural path parameter coefficients. Changes in $\mathrm{R}$ square values were used to assess the effect of certain latent independent variables on latent dependent variables. The effect of $f^{2}$ value was calculated using the formula:

$$
\mathrm{f}^{2}=\frac{\mathrm{R}_{\text {included }}^{2}-\mathrm{R}_{\text {excluded }}^{2}}{1-\mathrm{R}_{\text {included }}^{2}}
$$

$\mathrm{R}_{\text {included }}^{2}$ and $\mathrm{R}_{\text {excluded }}^{2}$ were the $\mathrm{R}$-square of the dependent latent variable when the predictors of latent variables were used or excluded in structural equations. The $f^{2}$ value 
equaled to $0.02,0.015$ and 0.35 . They were interpreted by the predictors of latent variables to have small, medium and large effects on the structural level.

The PLS model for the construct model was also evaluated by looking at Q-square of predictive relevance to measure how well the observed values that were generated by the model and its parameter estimation. A Q-square value greater than 0 (zero) indicated that the model had a predictive relevance value whereas a $Q$-square value less than 0 indicated that the model had less predictive relevance.

Hypothesis Testing. According to Sarwono and Narimawati (2015: 178), hypothesis testing in SEM PLS could be performed by comparing t-value to t-table. The testing steps included among others: formulating the hypotheses, calculating the value of t-table, calculating the value of t-count, and conducting hypothesis testing. According to Jogiyanto and Abdillah (2009: 197), the score of the coefficient path or inner model shown by the value of t-statistic should be above 1.96 for hypothesis testing at 5 percent alpha.

Some of the fit indexes used in SEM-PLS were: in the outer model stage, it included outer loading, cross loading, composite reliability, cronbach's alpha, AVE, AVE roots whereas in the inner model stage, it included path coefficient test both indirect effect and direct effect. SEM-PLS hypothesis testing method used was structural model. Structural model testing was carried out to find out the effect of the path coefficient directly or indirectly between the variables under the research, the effect between the group and its indicator, between the constructs either endogenous or exogenous or between the two. Ferdinand (2002) stated that the structural model was a model that describes the correlation between constructs or hypothesized research variables which explain the causality including tiered causality.

Mediation Test Using Sobel Test. In this research, there might be intervening variables between independent and dependent variables. It meant that the effect of independent variable on dependent variable was not directly but through a process of transformation represented by the intervening variables (Baron and Kenney, 1986; in Jogiyanto and Abdillah, 2009: 117). The correlation of intervening variables between independent and dependent variables could be described as the following:

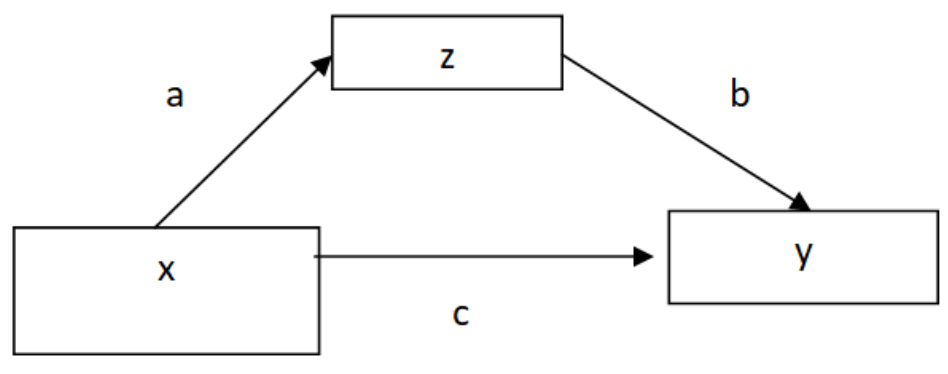

Figure 1 - Intervening (Mediation)

Figure 1 above was called partial mediation model in which one hypothesis described the direct relationship (from $X$ to $Y$ ) and the hypothesis described the indirect relationship (from $X$ to $Y$ via $Z$ ) from the independent variable to the dependent variable.

\section{RESULTS OF STUDY}

Analysis Results Using Structural Equation Model of Partial Least Square (SEM-PLS). According to Wiyono (2011: 428), standard loading values greater than 0.50 could be regarded as a valid research indicator whereas Jogiyanto and Abdillah (2009: 60) suggested that loading values greater than 0.50 was considered to be significantly practical. Thus, the higher the loading value, the more important the role of loading in interpreting the matrix factor. Figure of structural model using SEM Smart PLS 2.0 Algorithm (initial model) is presented in the following figure: 


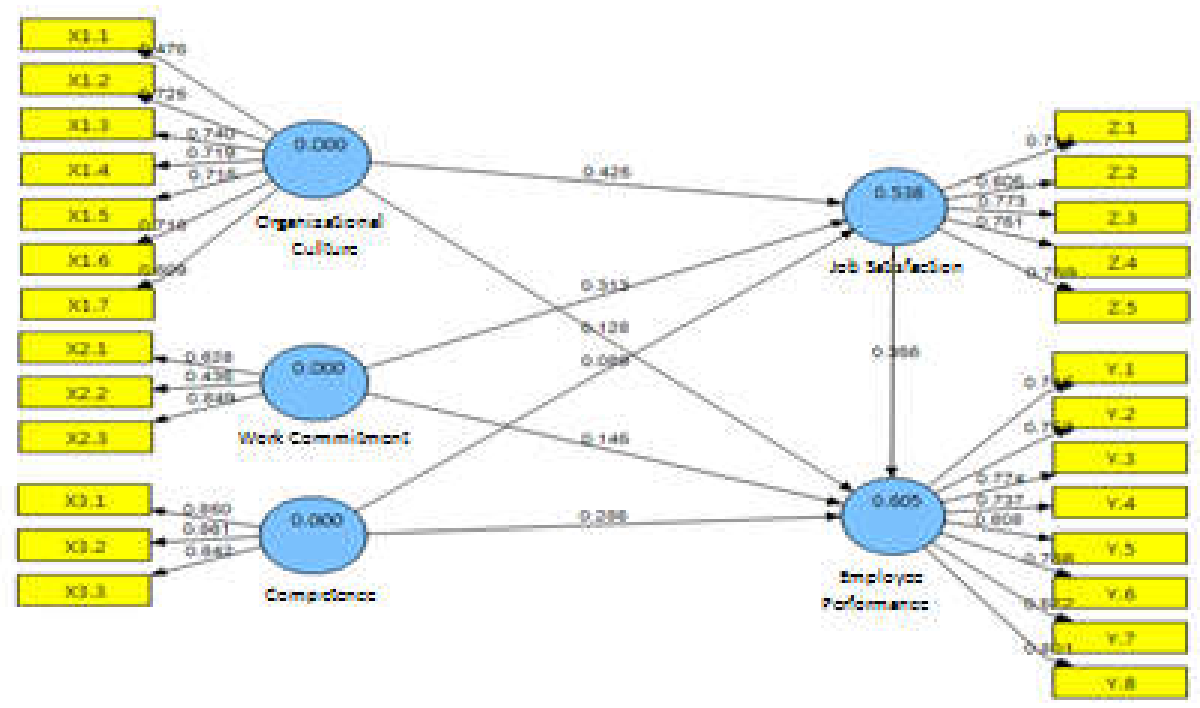

Figure 2 - The Results of SEM-PLS Algorithm (Initial Model)

Based on the range of loading values processed by using SEM-PLS (initial model), it showed that organizational culture was measured by 7 research indicators with a loading range of $0.476-0.740$. Thus, there was an invalid research indicator that was X1.1 with loading value of 0.476 in which it should be dropped from this research. Then, work commitment was measured by 3 research indicators and had a loading range of $0.436-0.849$. Thus, work commitment that had the X2.2 indicator was invalid so that X2.2 indicator must be dropped. Furthermore, competence was measured by 3 research indicators with loading value of $0.842-0.861$. Since the range of loading values greater than 0.50 , it meant that all research indicators were already valid. Furthermore, job satisfaction was measured by 5 research indicators and had a loading range of $0.715-0.805$. Since the loading range was greater than 0.50 , it meant that all research indicators were already valid. Meanwhile, the variable of employee performance was measured by 8 research indicators with loading range of $0.622-0.808$. Since the loading range was greater than 0.50 , it meant that all research indicators were already valid.

The figure of the structural model using SEM Smart PLS 2.0 Algorithm (after the improvement) is presented in the following figure:

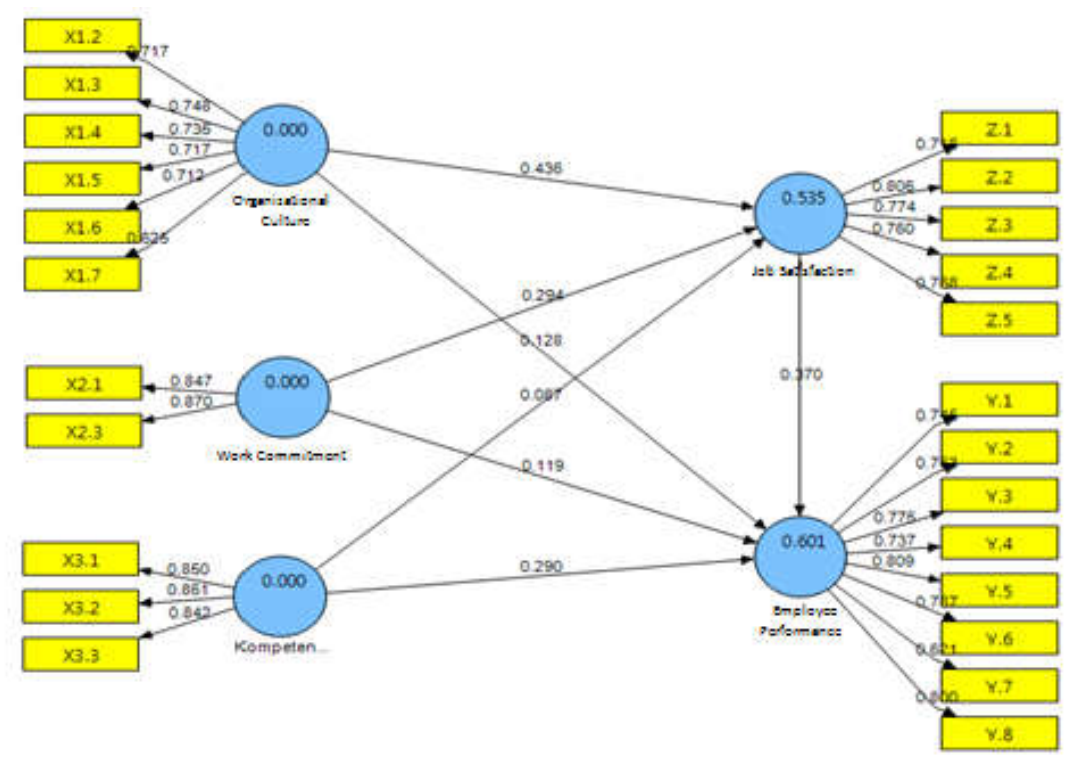

Figure 3 - The Results of SEM-PLS Algorithm (Model after the Improvement) 
Based on the loading range of each research indicator, all indicators of each research variable to be used in hypothesis testing were valid, this could be seen from the loading range of each research variable namely organizational culture measured by 6 indicators (X1 .2-X1.7) with a loading range of $0.625-0.748$ which was already greater than 0.50 . It meant that the six indicators of organizational culture were valid.

Then, work commitment was measured by 2 research indicators (X2.1-X2.3) with a loading range of $0.847-0.870$ that was already greater than 0.50 . It meant that all research indicators were already valid. The competence variable was measured by 3 research indicators $(0.842-0.861)$ in which it was already greater than 0.50 . It meant that all research indicators were valid in measuring competence variable. Furthermore, job satisfaction variable was measured by 5 research indicators (Z1-Z5) with loading range of $0.716-0.806$. Since the loading range was greater than 0.50 , it meant that all the research indicators were valid. In addition, employee performance variable was measured by 8 research indicators (Y.1-Y.8) with a loading range of 0.621-0.809 which was greater than 0.50 . It meant that all research indicators were valid in measuring employee performance variable.

Construct Reliability Test. The reliability test in SEM-PLS analysis was performed to show the accuracy, consistency and accuracy of a measuring instrument in the measurement. In other words, reliability is a measure that shows the stability and consistency of an instrument in measuring a concept or a variable. The reliability was measured to see the value of cronbach's alpha with composite reliability.

Cronbach's Alpha. Cronbach's alpha in reliability test was used to measure the lower limit of a construct's reliable value. Based on the above description, the following will present the value of cronbach's alpha in the initial model and the model after the improvement that was processed suing SEM-PLS in the table below:

Table 1 - The Values of Cronbach's Alpha Before and After the Improvement

\begin{tabular}{|c|l|c|c|}
\hline No & \multicolumn{1}{|c|}{ Research Variables } & $\begin{array}{c}\text { Initial Model of } \\
\text { Cronbach's Alpha }\end{array}$ & $\begin{array}{c}\text { Cronbach's Alpha Model } \\
\text { After the Improvement }\end{array}$ \\
\hline 1 & Organizational Culture & 0.800 & 0.802 \\
2 & Work Commitment & 0.553 & 0.643 \\
3 & Competence & 0.810 & 0.810 \\
4 & Job Satisfaction & 0.823 & 0.823 \\
5 & Employee Performance & 0.892 & 0.892 \\
\hline
\end{tabular}

Table 1 is a comparison of cronbach's alpha values before and after the improvement from each research variable to be used in hypothesis testing. It could be seen that the value of cronbach's alpha for work commitment was less than 0.60 . It meant that every research indicator was less reliable in measuring work commitment because after the improvement, the value of cronbach's alpha was already above 0.60 . It was based on the opinion put forward by Jogiyanto and Abdillah (2009: 132) that the alpha value of rule of thumb or composite reliability must be greater than 0.70 although a value of 0.60 is still acceptable in the exploitation study. Thus, from that opinion, it can be concluded that all the research indicators used in hypothesis testing were already reliable in measuring every research indicator.

Composite Reliability. Composite reliability was used to measure the real value of construct reliability so that it presented the ratio of composite reliability before the improvement (initial model) and after the improvement in which it will be presented in the following table.

Table 2 - Composite Reliability Before and After the Improvement with the Research Indicators

\begin{tabular}{|l|l|l|l|}
\hline No. & Research Variables & $\begin{array}{l}\text { The Initial Model of } \\
\text { Composite Reliability }\end{array}$ & $\begin{array}{l}\text { Composite Reliability } \\
\text { Model After the Improvement }\end{array}$ \\
\hline 1 & Organizational Culture & 0.854 & 0.859 \\
2 & Work Commitment & 0.761 & 0.848 \\
3 & Competence & 0.888 & 0.888 \\
4 & Job Satisfaction & 0.876 & 0.876 \\
5 & Employee Performance & 0.914 & 0.914 \\
\hline
\end{tabular}


Table 2 is comparison results of composite reliability before the improvement (initial model) and after the improvement. The values of composite reliability, after the improvement, were much better compared to the before-the-improvement model (initial model). Therefore, the model used in this research was the model that had been through the improvement.

Analysis of Structural Model (Inner Model). Analysis of structural model (inner model) was a structural model that linked among the latent variables. Therefore, before conducting the analysis of structural model (inner model), the structural model of bootstrapping (initial model) would first be presented which can be seen through the following figure:

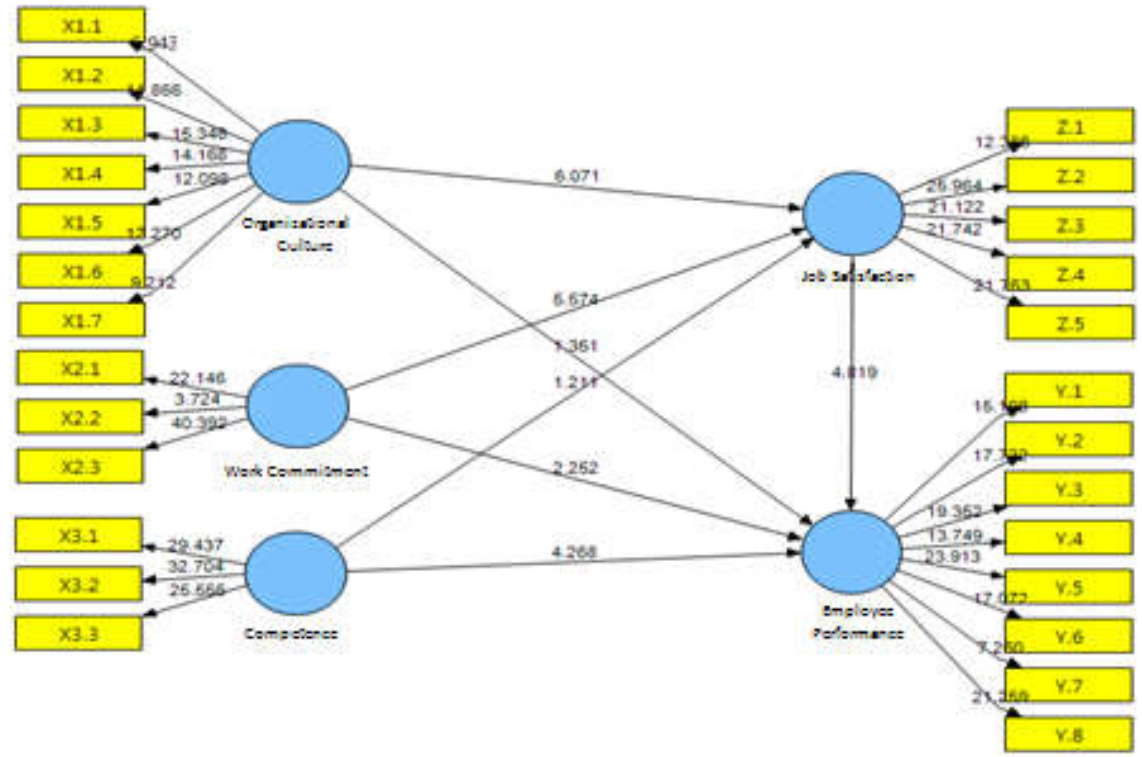

Figure 4 - The Results of Bootstrapping (Initial Model) Using SEM-PLS

Then structural model of bootstrapping (after the improvement) will be presented which can be seen in the following figure:

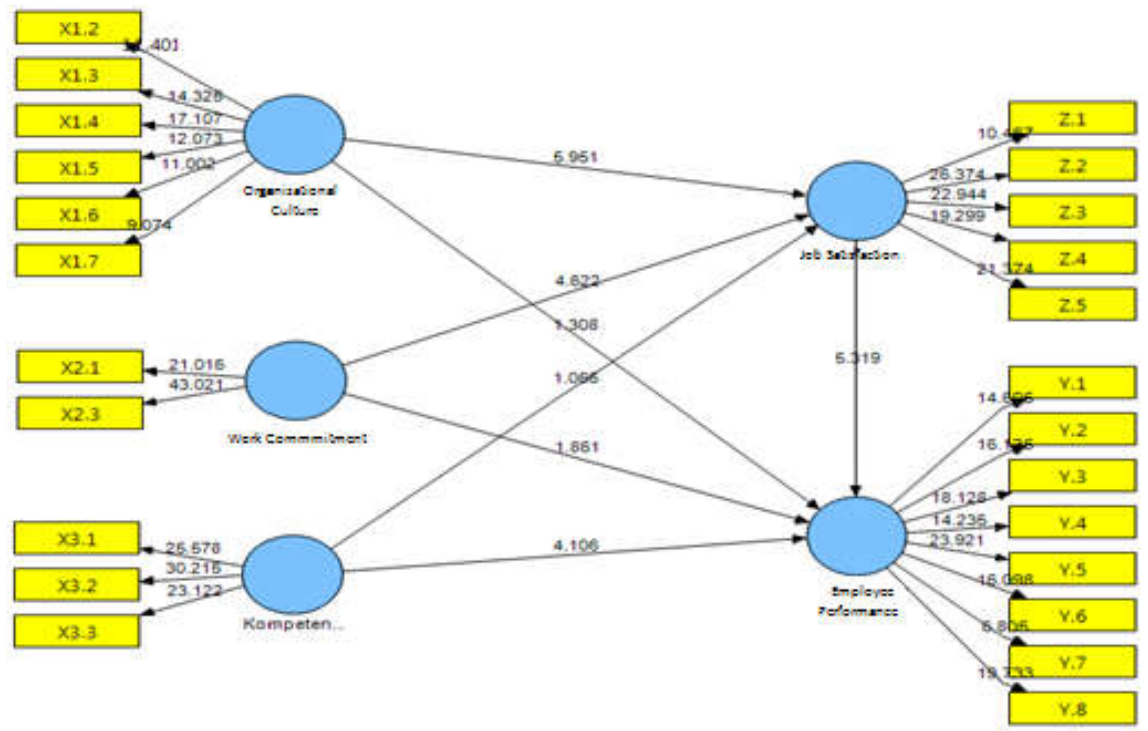

Figure 5 - The Results of Bootstrapping (After the Improvement) Using SEM-PLS

Based on the structural model (inner model) through the results of bootstrapping before and after the improvement, the determinant coefficient ( $R$ square), predictive relevance $(Q$ square) and goodness of fit would be done first. 
Analysis of Determination Coefficient. Analysis of determinant coefficient was used to measure the level of variation improvement of independent variable to dependent variable. The higher the value of R2 meant that the prediction model with the proposed research model was the better. Based on the result of bootstrapping in analysis model of SEM-PLS, $\mathrm{R} 2$ values of each endogenous variable are:

Table 3 - The Values of R Square

\begin{tabular}{|c|c|}
\hline Research Variables & R Square \\
\hline Job Satisfaction (Z) & 0.535 \\
\hline Employee Performance & 0.601 \\
\hline
\end{tabular}

Based on table 3 , the $\mathrm{R}$ square was 0.535 . It could be interpreted that $53.50 \%(0.535 \mathrm{x}$ 100 ) of job satisfaction could be explained by organizational culture, work commitment and competence. Meanwhile, the remaining 46.5\% (1 - $0.535 \times 100)$ was determined by other factors not included in this research model. Then, the $R$ square $=0,601$ could be interpreted that $60.10 \%(0,601 \times 100)$ of employee performance could be explained by the existence of organizational culture, work commitment, competence and employee satisfaction. Meanwhile, the remaining $39.9 \%(1-0.601 \times 100)$ was determined by other factors not included in this research.

Analysis of Predictive Relevance ( $Q$ Square). Analysis of predictive relevance ( $Q$ square) was used to describe good predictive level of endogenous variables. These results were determined by regression equation as the following:

$$
\mathrm{Q} 2=1-\left(1-\mathrm{R} 1^{2}\right)\left(1-\mathrm{R} 2^{2}\right)\left(1-\mathrm{Rp}^{2}\right)=0.814
$$

Based on the calculation of $Q$ square, it produced a $Q$ square value of 0.814 . Then the value of $Q$ square greater than 0 can be concluded that the organizational culture variable, work commitment, competence, and job satisfaction had a good level of prediction on employee performance.

Test of Goodness of Fit Model. The test on the structural model equation (SEM) was performed by looking at the $\mathrm{R}$ square value which included the test of goodness of fit. Based on the results of data processing using SEM-PLS, the $R$ square and $Q$ square could be presented in the following table:

Table 4 - The Values of R Square and Q Square

\begin{tabular}{|c|c|}
\hline Research Variables & Values \\
\hline Job Satisfaction & 0.535 \\
Employee Performance & 0.601 \\
Predictive Relevance (Q square) & 0.814 \\
\hline
\end{tabular}

Based on table 4 , on the predictive relevance value of this research model, the $Q$ square value was 0.814 in which it was already high. Thus, it could be concluded that this model was feasible to be used to test the hypothesis.

Hypothesis Testing:

The Effect of Organizational Culture on Job Satisfaction. Based on the test results, the t-statistic was 5.951, greater than t-table 1.96. It could be interpreted that organizational culture had a significant effect on job satisfaction. Therefore, in this research, the first hypothesis $(\mathrm{H} 1)$ was accepted.

The Effect of Work Commitment on Job Satisfaction. Based on the result of hypothesis testing, the t-statistic was 4.622 , bigger than t-table 1.96. It could be interpreted that work commitment had a significant effect on job satisfaction. Thus, in this research, the second hypothesis $(\mathrm{H} 2)$ was accepted.

The Effect of Competence on Job Satisfaction. Based on the test results, the t-statistic was 1.066, smaller than t-table 1.96. Thus, it could be concluded that competence had no 
significant effect on job satisfaction. Therefore, in this research, the third hypothesis $(\mathrm{H} 3)$ was rejected.

The Effect of Organizational Culture on Employee Performance. Based on the test results, the t-statistic was 1.308 , smaller than t-table 1.96. Thus, it could be interpreted that organizational culture had no significant effect on employee performance. Thus, in this research, the fourth hypothesis $(\mathrm{H} 4)$ was rejected.

The Effect of Work Commitment on Employee Performance. Based on the results of the test analysis, the t-statistic was 1.861 , smaller than t-table 1.96 . Thus, it could be concluded that work commitment had no significant effect on employee performance. Thus, in this research, the fifth hypothesis (H5) was rejected.

The Effect of Competence on Employee Performance. Based on the results of the analysis test through the questionnaire distribution, the t-statistic value was 4.106, greater than t-table 1.96. Thus, it could be interpreted that the competence had a significant effect on employee performance. Thus, from the analysis results of this research, the sixth hypothesis (H6) was accepted.

The Effect of Job Satisfaction on Employee Performance. Based on result of analysis in this research, the t-statistic value was 5.319 , bigger than $t$-table value 1.96 . Thus, it could be concluded that job satisfaction had a significant effect on employee performance. Thus, from the results of the analysis in this research, the seventh hypothesis $(\mathrm{H} 7)$ was accepted.

The Results of Mediation Test. The result of the path test on the effect of organizational culture through job satisfaction on employee performance showed that the direct effect was 0.128 while the indirect effect was 0.162 . Thus, the total effect was 0.289 . Therefore, it could be said that the effect of organizational culture through job satisfaction on employee performance was 0.289 . To test the mediation effect, it needed to be tested using the Sobel test as the following:

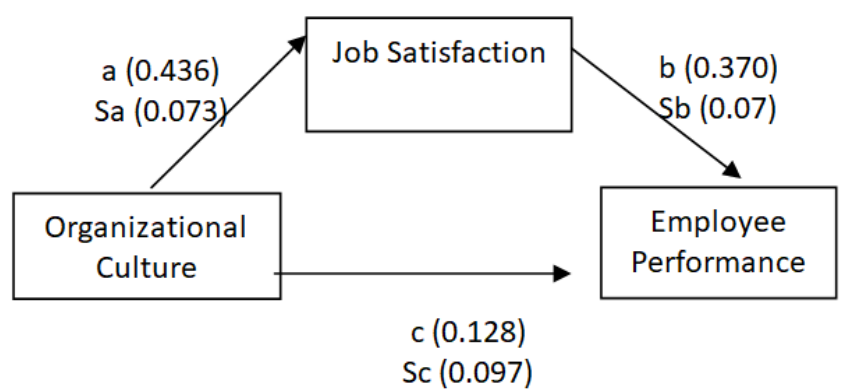

Figure 6 - Sobel Test to the Effect of Organizational Culture on Employee Performance through Job Satisfaction

Based on the calculation from the online calculator, the value of $Z$ was 3.958. The $Z$ value $(3.958)>1.96$, it could be concluded that job satisfaction mediates the effect of organizational culture on employee performance. Thus, in this research, the empirical findings found that job satisfaction perceived by employees during work at PT Bank Rakyat Indonesia (Persero) Tbk, Regional Office of Semarang could mediate the effect of organizational culture on employee performance.

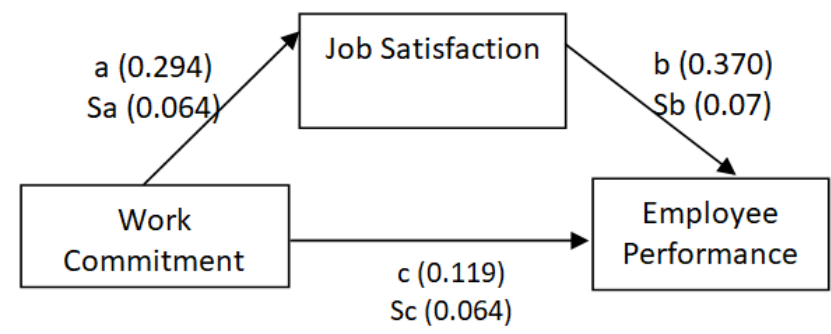

Figure 7 - Sobel Test to the Effect of Work Commitment on Employee Performance through Job Satisfaction 
Based on the results of the path test using SEM-PLS on the effect of work commitment through job satisfaction on employee performance, the direct effect was 0.119 whereas the indirect effect of work commitment through job satisfaction on employee performance was 0.109. Based on the results of the SEM-PLS path test above, the total effect of organizational commitment through job satisfaction on employee performance was 0.228 .

Based on the calculation from the online calculator, the value of $Z$ was 3.467 . The $Z$ value $(3.467)>1.96$, it could be concluded that job satisfaction mediated the effect of work commitment on employee performance. Thus, in this research, empirical findings found that job satisfaction perceived by employees during work at PT Bank Rakyat Indonesia (Persero) Tbk, Regional Office of Semarang could encourage the employee to have high work commitment which affected the employee performance.

Based on the results of path test on the effect of competence through job satisfaction on employee performance, the direct effect was 0.290 whereas the indirect effect was 0.032 . Thus, the total effect of competence through job satisfaction on employee performance was 0.322 . To test the effect of such mediation, it needed to be tested using the Sobel test as the following:

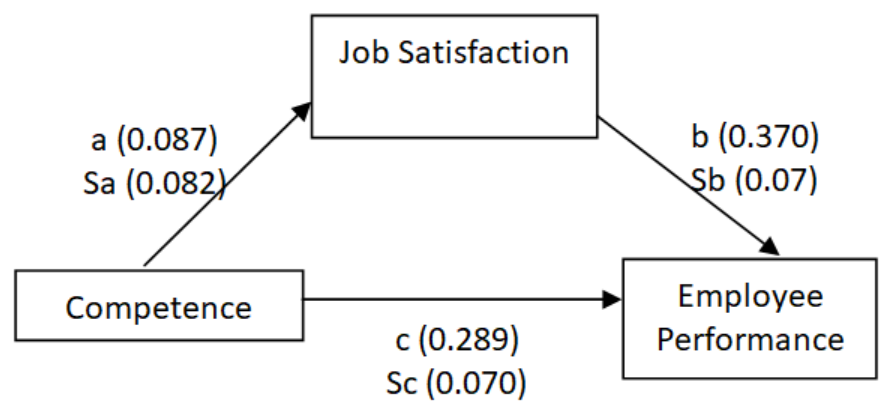

Figure 8 - Sobel Test on the Effect of Competence on Employee Performance through Job Satisfaction

Based on the calculation from the online calculator, the $Z$ value was 1.040 . The $Z$ value $(1.040)<1.96$, it could be concluded that job satisfaction could not mediate the effect of competence on employee performance. These results indicated that competence did not encourage employee job satisfaction in PT Bank Rakyat Indonesia (Persero) Tbk, Regional Office of Semarang.

\section{DISCUSSION OF RESULTS}

The Effect of Organizational Culture on Job Satisfaction. The organizational culture in Bank Rakyat Indonesia (Persero) Tbk was integrity, professionalism, trust, innovation and customer centric. Based on the results of the observation through the distribution of questionnaires, it showed that employees' perceptions regarding the implementation of organizational culture so far had been quite good. It was based on the criteria of description analysis 3.40-4.19 which could be interpreted as good/ high (Muhidin and Abdurahman, 2011: 146). It is considered that the application of organizational culture was already quite good because of the innovative ideas. In addition, it was known that the employees' perceptions had provided an opportunity for every employee to always create innovative ideas in doing the job.

Then, it is seen from the employee's perception to the detail attention in doing the job. On average, the employees had perceived well because the score had ranged from 3.40 to 4.19. The reason was because every employee had had detail attention of every job and was always oriented to the work results in completing the work, especially within the scope of PT Bank Rakyat Indonesia (Persero) Tbk, Regional Office of Semarang.

Furthermore, the employees' perceptions of PT Bank Rakyat Indonesia (Persero) Tbk, Regional Office of Semarang had responded that leaders often paid attention to employees 
during the work. In addition, every employee of PT Bank Rakyat Indonesia (Persero) Tbk, Regional Office of Semarang always finished the work which was more oriented to teamwork.

Then employees were required to work aggressively in completing the job that became their respective responsibilities. It could be seen that every employee was required to perform the duties that were his/her responsibility and in addition the employees had been comfortable with the work conditions at PT Bank Rakyat Indonesia (Persero) Tbk, Regional Office of Semarang.

Based on the test results on the effect of organizational culture on employee job satisfaction at PT Bank Rakyat Indonesia (Persero) Tbk, Regional Office of Semarang, empirically it was found that organizational culture had a significant effect on employee job satisfaction which meant that efforts in improving employee job satisfaction could be improved through organizational culture.

Research conducted by Koesmono (2005) and Widagdo (2013) supported that organizational culture affected job satisfaction. Meanwhile, Rohayati (2013) and Sabri et al. (2011) suggested that it had a positive and significant effect on job satisfaction. Thus, this research supported the research conducted by Koesmono (2005), Widagdo (2013), and Sabri et al. (2011) and did not support the research conducted by Rohayati (2013).

The Effect of Work Commitment on Job Satisfaction. Based on the analysis results obtained from the results of field observation at PT Bank Rakyat Indonesia (Persero) Tbk, Regional Office of Semarang and its branches, it obtained the findings from employees' perceptions in PT Bank Rakyat Indonesia (Persero) Tbk, Regiona Office of Semarang in which they had given good responses because the score was in the range of 3.40-4.19. It could be seen from the pride of the employees working at PT Bank Rakyat Indonesia (Persero) Tbk, Regional Office of Semarang.

In addition, the employees stated that they did not intend to leave the company. Thus, based on the perception of the employees working at PT Bank Rakyat Indonesia (Persero) Tbk, Regional Office of Semarang, they would continue working and did not intend to leave the company.

Then, from the analysis of the effect of work commitment on job satisfaction at PT Bank Rakyat Indonesia (Persero) Tbk, Regional Office of Semarang, it showed that work commitment had a significant effect on employee job satisfaction.

Research conducted by Arifah and Romadhon (2015) found the findings that work commitment affected the employee job satisfaction. Meanwhile, Sunarno and Liana (2015) found that work commitment had no effect on job satisfaction. In addition, Adekola (2012) found that there was a significant effect between work commitment and job satisfaction. Thus, this research supported the research conducted by Arifah and Romandhon (2015) and Adekola (2012), but did not support the research conducted by Sunarno and Liana (2015).

The Effect of Competence on Job Satisfaction. Based on the research findings through the distribution of questionnaires, the findings showed that the perception of the respondents about the employee competence of PT Bank Rakyat Indonesia (Persero) Tbk, Regional Office of Semarang was already high because it was in the range between 3.40-4.19 score. It could be known that the level of knowledge owned by the employees working at PT Bank Rakyat Indonesia (Persero) Tbk, Regional Office of Semarang was good. The reason was because the employees already had the ability to do the work they had handled so far.

Next, if it was viewed from the expertise of employees in doing the work, it showed that the expertise of the employees working at PT Bank Rakyat Indonesia (Persero) Tbk, Regional Office of Semarang was considered as high. It could be seen that the employees working at PT Bank Rakyat Indonesia (Persero) Tbk, Regional Office of Semarang perceived that all employees already had the competence of every job they handled so far.

Employees' perceptions had given enough responses to the behavior or attitude in running work activities. This could be seen from the employee's responses in which they already had behavior or work attitude in doing the work they have handled so far.

Based on the results of the path test, it was found empirically that employee competence proved to have no significant effect on employee job satisfaction at PT Bank 
Rakyat Indonesia Tbk, Regional Office of Semarang because there were still a small number of employees who had less expertise in the field of competence they had handled. In addition, there were still a small number of employees who were less satisfied with the employee placement that was less in accordance with the field of competence owned by employees so far.

The findings of previous research supporting that competence had a significant effect on job satisfaction were Bagia (2014), Zainuddin et al. (2015), Murgianto and Suhermin (2016), and Arifin (2015). Meanwhile, research conducted by Dhermawan et al. (2016) did not support that competence had an insignificant effect on employee performance. Thus, this research conducted by the researchers did not support the research conducted by Bagia (2014), Zainuddin (2015), Murgianto and Suhermin (2016), and Arifin (2015), and supported the research conducted by Dhermawan et al. (2016).

The Effect of Organizational Culture on Employee Performance. The analysis results of this research indicated that the implementation of organizational culture conducted by PT Bank Rakyat Indonesia (Persero) Tbk, Regional Office of Semarang had not improved employee performance. It was seen that the employees' perception of PT Bank Rakyat Indonesia (Persero) Tbk, Regional Office of Semarang was still lacking, so the working conditions needed to be improved in order to provide comfort and create an atmosphere supporting the satisfaction for every employee.

Research conducted by Suzanto and Solihin (2012), Soedjono (2005), Wanjiku and Agusioma (2014) supported that organizational culture affected the employee performance whereas the research findings of Nurhalim and Sudarsih (2015) found that organizational culture had no effect on employee performance. Thus, this research did not support the research conducted by Suzanto and Solihin (2012), Soedjono (2005) and Wanjiku and Agusioma (2014), and supported the research conducted by Nurhalim and Sudarsih (2015).

The Effect of Work Commitment to Employee Performance. The analysis result of this research found that work commitment had an insignificant effect on employee performance in PT Bank Rakyat Indonesia (Persero) Tbk, Regional Office of Semarang. The reason was that based on employee perception, work commitment still needed to be enhanced through the attention of leader to always pay attention to the salary and allowance aspects so that the employees might be satisfied and they would keep working and not intended to leave the company.

The previous research conducted by Gunawan (2015), Widi (2015), and Giri et al. (2016) found that work commitment had a significant effect on employee performance. Thus, this research conducted by the researchers did not support the previous research.

The Effect of Competence on Employee Performance. Based on the findings of this research namely the effect of competence on employee performance at PT Bank Rakyat Indonesia (Persero) Tbk, Regional Office of Semarang, it was obtained the empirical findings that competence had a significant effect on employee performance. Factors that could improve employee performance were determined by the competence (knowledge and expertise) owned by every employee in completing their works at PT Bank Rakyat Indonesia Tbk, Regional Office of Semarang.

Findings from the previous research conducted by Zainuddin et al, (2015) stated that competence affected employee satisfaction and performance. Meanwhile, research conducted by Murgianto and Suhermin (2016) found that competence affected employee performance. Another research conducted by Dhermawan et al. (2016) showed that competence had a significant effect on employee performance. Thus, this research supported research conducted by Zainuddin et al, (2015) and Murgianto and Suhermin (2016) and did not support the research conducted by Dhermawan et al. (2016).

The Effect of Job Satisfaction on Employee Performance. Based on the observations conducted at PT Bank Rakyat Indonesia (Persero) Tbk, Regional Office of Semarang which could be seen from the work handled by the employees, most employees' perceptions had been satisfied with the work they had handled so far. In addition, the working relationship between the leaders and the employees had already created a good working relationship. 
Mostly, one colleague and another at PT Bank Rakyat Indonesia (Persero) Tbk, Regional Office of Semarang supported the creation of daily work settlements that affected employee performance. In addition, the terms of promotion of positions conducted by PT Bank Rakyat Indonesia (Persero) Tbk, Regional Office of Semarang had provided job satisfaction for every employee. Similarly, salaries and benefits were received by employees in which, there were still employees who received a low enough allowance.

The results of hypothesis testing had been conducted showed that job satisfaction had positive and significant effect to employee performance. The higher the employee job satisfaction then the employee performance could be further improved. Thus, this research found the factors that could improve employee performance was job satisfaction perceived by each employee. This was in accordance with the theory revealed by Gibson et al, (2004: 98) which explained that job satisfaction led to an increase or decrease in employee performance so that satisfied employees would be more productive compared with unsatisfied employees. When the employees feel dissatisfaction over their work, it would cause the performance to decline. In addition, Gibson et al, (2004: 99) revealed that it illustrated a reciprocal relationship between job satisfaction and employee performance.

The findings of this research were in line with research conducted by Inuwa (2015) who found that job satisfaction had a positive and significant effect on employee performance. Similarly, the research conducted by Mardiani and Dewi (2015) found that job satisfaction had a significant effect on employee performance. Another research in line with this research was Vrinda and Jacob's (2015) research found that job satisfaction affected employee performance. However, it was different from the research findings of Supiyanto (2015) who found that job satisfaction did not affect the employee performance.

Discussion on Indirect Effect. Test results on indirect effect explained the effect of intervening variable of job satisfaction on the correlation between independent variable and dependent variable. The intervening variable (mediation) could strengthen or weaken the correlation of independent variable and dependent variable. Explanation of indirect effect of this research could be explained as the following:

The test results of indirect effect from the sobel test showed that job satisfaction mediated the effect of organizational culture on employee performance in PT Bank Rakyat Indonesia (Persero) Tbk, Regional Office of Semarang. Good organizational culture could improve employee job satisfaction that would give effect on improving employee performance. The operational implementation of the organization was already running well. According to the employees' perception of the employees working at PT Bank Rakyat Indonesia (Persero) Tbk, Regional office of Semarang, they always gave detail attention on the tasks or jobs they had handled so far. In addition, any work that had been handled was always oriented to the work results in completing the task. This showed a good organizational culture which would increase employee job satisfaction. If the employees get job satisfaction, then they would work without having to be supervised by the leaders so that their performance would be higher. This was in accordance with the theory revealed by Gibson et al. (2004: 98) who explained that job satisfaction caused an increase or decrease in employee performance so that satisfied employees would be more productive than unsatisfied employees. If an employee feels unsatisfied with his or her work, it would cause a decrease in performance. In addition, Gibson et al. (2004: 99) revealed that it illustrated a reciprocal correlation between job satisfaction and employee performance.

The test results of indirect effect from the sobel test showed that job satisfaction mediated the effect of organizational commitment on employee performance in PT Bank Rakyat Indonesia (Persero) Tbk, Regional Office of Semarang. A high commitment would make a person feel satisfied with what they are doing. This research indicated that level of employee commitment in PT Bank Rakyat Indonesia (Persero) Tbk, Regional Office of Semarang needed to be improved in order to increase employee satisfaction and improve employee performance. This research also found that work commitment had an insignificant effect on employee performance. Therefore it was necessary to increase employee job satisfaction as performed in mediation test in which job satisfaction was able to mediate the effect of work commitment on employee performance. 
The test results from indirect effect of the sobel test showed that job satisfaction did not mediate the effect of competence on employee performance in PT Bank Rakyat Indonesia (Persero) Tbk, Regional Office of Semarang. This could be explained because employees who had high work competence might not be satisfied with their works. However, high competence would facilitate employees in performing their duties. Competence owned by the employees could encourage someone to finish the job appropriately so that their performances would increase. Therefore, competence was still needed to improve employee performance in PT Bank Rakyat Indonesia (Persero) Tbk, Regional Office of Semarang.

Implication of the Findings. Implication of the findings of this research expected that the findings from the field observations could be used as the development of management theory of human resource, especially to the matters relating to organizational culture, work commitment, competence, job satisfaction, and employee performance in the scope of banking.

Practical Implication. The implications of this research indicated that the research findings provided a practical contribution that could explain the research gap in this research. In addition, it could provide empirical findings to improve the performance of bank employees. Thus, it is advisable to improve organizational culture, work commitment, competence, and job satisfaction. Thus, PT Bank Rakyat Indonesia (Persero) Tbk, Semarang Regional Office needs to improve the aspects that can enhance job satisfaction such as: salary and allowances, employment relationship between the leaders and the employees, and attention to the provisions of promotion conducted so far by PT Bank Rakyat Indonesia (Persero) Tbk, Regional Office of Semarang.

Limitations of the Research. The limitations of this research was that the researchers only conducted the observations and did not conduct interview so that the conclusions were drawn only based on the data collected by using written instrument (questionnaire).

Novelty of the Research. The novelty of this research, compared to the previous research, was that it emphasized more in examining the effect of organizational culture, work commitment, and competence to employee performance by using job satisfaction as the intervening variable. On average, the previous researchers applied multiple linear regression analysis whereas this research applied path analysis using Structural Model Equation (SEM) approach through the application of Smart Partial Least Square (SEM PLS 2.0).

\section{CONCLUSION}

Based on the analysis results and discussion from the research findings, some conclusions from the analysis results can be drawn as the following:

The analysis results of this research namely the effect of organizational culture on employee job satisfaction at PT Bank Rakyat Indonesia (Persero) Tbk, Regional Office of Semarang empirically found that organizational culture had a significant effect on job satisfaction of the employees working in PT Bank Rakyat Indonesia (Persero) Tbk, Regional Office of Semarang. Thus, in this research, the hypothesis was accepted.

The research findings on the effect of work commitment to employee job satisfaction empirically found that work commitment had a significant effect on job satisfaction at PT Bank Rakyat Indonesia (Persero) Tbk, Regional Office of Semarang. Thus, in this research, the hypothesis was accepted.

The research findings on the effect of competence on job satisfaction at PT Bank Rakyat Indonesia (Persero) Tbk, Regional Office of Semarang empirically found that the competence had a significant effect on job satisfaction of the employees working in PT Bank Rakyat Indonesia Tbk, Regional Office of Semarang. Thus, in this research, the hypothesis was rejected.

The analysis results of the research on the effect of organizational culture on employee performance at PT Bank Rakyat Indonesia (Persero) Tbk, Regional Office of Semarang found that organizational culture had no significant effect on employee performance at PT Bank Rakyat Indonesia Tbk, Regional Office of Semarang. Thus, the research hypothesis was rejected. 
The analysis results of the research on the effect of work commitment on employee performance empirically obtained the findings that work commitment had no significant effect on employee performance, so the hypothesis was rejected.

The analysis results of the research on the effect of competence on employee performance at PT Bank Rakyat Indonesia (Persero) Tbk, Regional Office of Semarang found empirically that competence had a significant effect on employee performance. Thus, the hypothesis was accepted.

The analysis results of the research found that job satisfaction had a significant effect on employee performance of the employees working in PT Bank Rakyat Indonesia (Persero) Tbk, Regional Office of Semarang. Thus, the research hypothesis was accepted.

\section{REFERENCES}

1. Adekola, B. (2012). The Impact of Organizational Commitment on Job Satisfaction: A Study of Employees at Nigerian Universities. International Journal of Human Resource Studies 2(2): 1-17.

2. Arifah, D.A., \& Romadhon, C. (2015), Pengaruh Komitmen Organisasi, Komitmen Profesional dan Gaya Kepimpinan terhadap Kepuasan Kerja dengan Motivasi sebagai Variabel Interverning. Conference in Business, Accounting, and Management 2(1): 358369.

3. Arifin, M. (2015). Pengaruh Kompetensi, Motivasi, dan Budaya Organisasi Kepuasan Kerja dan Prestasi Guru SMA di Kota Jayapura, Papua, Indonesia. Jurnal Studi Pendidikan Internasional 8(1): 1-9

4. Bagia, I.W. (2015). Perilaku Organisasi. Edisi Pertama. Cetakan Pertama. Yogyakarta: Graha IImu.

5. Bintoro \& Daryanto, (2017). Manajemen Penilaian Kinerja Karyawan. Edisi Pertama. Cetakan Pertama. Jakarta: Gaya Media

6. Dhermawan, A. A., Bagus, I.G.A., Sudibya, \& Utama, I.W.M. (2012). Pengaruh Motivasi, Lingkungan Kerja, Kompetensi dan Kompensasi terhadap Kepuasan Kerja dan Kinerja Pegawai di Lingkungan Kantor Dinas Pekerjaan Umum Provinsi Bali. Jurnal Manajemen Srtategi Bisnis dan Kewirausahaan 6(2): 173-182.

7. Edison, E. (2016). Human Resources Development: Pengembangan Sumber Daya Manusia. Edisi Pertama. Cetakan Pertama. Alfabeta. Bandung.

8. Ferdinand, A. (2003). Sustainable Competitive Advantage: Sebuah Eksplorasi Model Konseptual. Edisi Pertama. Cetakan Pertama. Fakultas Ekonomi Universitas Diponegoro. Semarang.

9. Gibson, J.L., Donnely, J.H., \& Ivancevich, J.M. (2004). Organizations: Behaviour, Structure and Process. 2nd ed. McGraw-Hill Companies Inc. Boston.

10. Giri, E.E., Nimran, U., Hamid, D., \& Musadieq, M.A. (2016). The Effect of Organizational Culture and Organizational Commitment to Job Involvement, Knowledge Sharing, and Employee Performance: A Study on Regional Telecommunications Employees of PT Telkom East Nusa Tenggara Province, Indonesia. International Journal of Management and Administrative Sciences 3(04): 20-33.

11. Gunawan, I.. (2015). Pengaruh Komitmen Organisasional dan Locus of Control Terhadap Kinerja Karyawan pada PT. Nikkatsu Electric Works Bandung. Jurnal Management Undergraduate 1(1): 1-12.

12. Indrawan, R. dan P. Yaniawati. (2014). Metodologi Penelitian. Edisi Pertama. Cetakan Pertama. Refika Aditama. Bandung.

13. Inuwa, M. (2015). The Impact of Job Satisfaction, Job Attitude and Equity on Employee Performance. The International Journal of Business \& Management 3(5): 288-291.

14. Javed, M. (2014). Determinants of Job Satisfaction and its Impact on Employee Performance and Turnover Intentions. International Journal of Learning \& Development 4(2): 120-135.

15. Jogiyanto \& Abdillah, W. (2009). Konsep dan Aplikasi PLS (Partial Least Square) untuk Penelitian Empiris. Edisi Pertama. Cetakan Pertama. Yogyakarta: BPFE. 
16. Koesmono, H.T. (2005). Pengaruh Budaya Organisasi terhadap Motivasi dan Kepuasan Kerja serta Kinerja Karyawan pada Sub sektor Industri Pengolahan Kayu Skala Menengah di Jawa Timur. Jurnal Manajemen dan Kewirausahaan 9(1): 30-44.

17. Luthans, F. (2002). Performance and Motivation. 2nd ed. Prentice Hall. New York.

18. Mardiani, A., \& Dewi, M.S. (2015). Pengaruh Kepuasan Kerja dan Komitmen Organisasional terhadap Kinerja Pegawai Bank Kalsel. Jurnal Wawasan Manajemen 3(3): 1-10.

19. Muhidin, S.A., \& Abdurahman, M. (2011). Analisis Korelasi, Regresi, dan Jalur Dalam Penelitian. Edisi Pertama. Cetakan Kedua. Jakarta: Pustaka Setia.

20. Murgianto, S. S. \& Suhermin, (2016). The Effects of Commitment, Competence, Work Satisfaction on Motivation, and Performance of Employees at Integrated Service Office of East Java. International Journal of Advanced Research 3(1): 378-396.

21. Nurhalim, F.D.S. \& Sudarsih, K.T. (2015). Pengaruh Budaya Organisasi, Lingkungan Kerja dan Organizational Citizenship Behavior terhadap Kinerja Karyawan Bank Indonesia Cabang Jember. Jurnal Manajemen 4(3): 1-15.

22. Panggabean, M.S. (2011). Manajemen Sumber Daya Manusia. Edisi Pertama. Cetakan Kedua. Bogor: Ghalia Indonesia.

23. Putrayana, Y. (2016). Pengaruh Kepuasan Kerja dan Komitmen Organisasi terhadap Organizational Citizenship Behavior dalam Meningkatkan Kinerja karyawan pada PT. Gelora Persada Mediatama, Semarang. Journal of Management 2(2): 1-6.

24. Robbins, S.P. \& Judge, T.A. (2015). Perilaku Organisasi: Konsep, Kontroversi, Aplikasi. Alih Bahasa Hadyana Pujaatmaka dan Benyamin Molan. Edisi Kedelapan. Cetakan Dua. Prenhallindo. Jakarta.

25. Rohayati, Y. (2013). Pengaruh Budaya Organisasi, Gaya Kepemimpinan, Motivasi Kerja terhadap Kepuasan Kerja dan Dampaknya terhadap Kinerja Pegawai di Lingkungan Kantor Kementerian Agama Kota Tasikmalaya, Jurnal Manajemen Universitas Siliwangi Tasikmalaya. 1(2): 1-5.

26. Sabri, P.S., Ullah, M., Ilyas \& Amjad, Z. (2011). Organizational Culture and Its Impact on the Job Satisfaction of The University Teachers of Lahore Pakistan, International Journal of Business and Social Science 2(24): 1-7.

27. Sarwono, J., \& Narimawati, U. (2015). Membuat Skripsi, Tesis dan Disertasi Partial Least Square SEM (PLS-SEM). Edisi Pertama. Cetakan Pertama. Yogyakarta: ANDI.

28. Sinambela, L.P. (2012). Kinerja Pegawai: Teori Pengukuran dan Implikasi. Edisi Pertama. Cetakan Pertama. Yogyakarta: Graha IImu.

29. Soedjono. (2005). Pengaruh Budaya Organisasi Terhadap Kinerja Organisasi dan Kepuasan Kerja Karyawan pada Terminal Penumpang Umum di Surabaya. Jurnal Manajemen dan Kewirausahaan 7(1): 22-47.

30. Sudarmanto. (2010). Kinerja dan Pengembangan Kompetensi Sumber Daya Manusia. Edisi Pertama. Cetakan Pertama. Pustaka Pelajar. Jakarta.

31. Sunarno, \& Liana, L. (2015). Pengaruh Komitmen Organisasional, dan Budaya Organisasi terhadap Kinerja Guru dimediasi Kepuasan Kerja (Studi Kasus pada Guru SMA Kesatrian Dalam Yayasan Pendidikan Kesatrian, Prosiding Seminar Nasional Multi Disiplin IImu dan Call for Paper Unisbank Semarang. 20-23 Juli: 1-20.

32. Sunyoto, D. (2012). Manajemen dan Pengembangan Sumber Daya Manusia dilengkapi dengan Budaya Organisasi Pengembangan Organisasi dan Outsourching. Edisi Pertama. Cetakan Pertama. CAPS. Yogyakarta.

33. Supiyanto, Y. (2015). Pengaruh Kompensasi, Kompetensi dan Komitmen Organisasional terhadap Kepuasan Kerja dan Kinerja Karyawan Koperasi. Prosiding Seminar Nasional STKIP PGRI Sidoarjo: 9 Mei: 1-25.

34. Suzanto, B., \& Solihin, A. (2012). Pengaruh Budaya Organisasi, Komunikasi Interpersonal dan Komitmen Organisasi terhadap Kinerja Pegawai pada Unit Network Management System Infratel PT. Telekomunikasi Indonesia, Tbk. Jurnal Ekonomi Bisnis dan Entrepreunership 6(2): 64-76.

35. Vrinda, N.N., \& Jacob, N.A. 2015. The Impact of Job Satisfaction on Job Performance. International Journal in Commerce, IT \& Social Sciences 2(2): 1-8. 
36. Wanjiku, N.A., \& Agusioma, N.L. 2010. Mengembangkan Kreativitas dalam Organisasi. Edisi Pertama. Kanisius. Yogyakarta. International Journal of Scientific and Research Publications 4(11): 1-10.

37. Wibowo. (2013). Perilaku dalam Organisasi. Edisi Pertama. Cetakan Pertama. Jakarta: Rajawali Pers.

38. Widagdo, H. (2013). Pengaruh Budaya Organisasi dan Komitmen Organisasi terhadap Kepuasan Kerja Karyawan pada PT. Nutrifood Indonesia di Jakarta. Jurnal Riset Manajemen Sains Indonesia (JRMSI) 4(1): 1-9.

39. Widi, P.S. (2015). Pengaruh Disiplin Kerja, Komitmen Organisasi dan Lingkungan Kerja Terhadap Kinerja Pegawai Negeri Sipil Balai Besar Wilayah Sungai Pemali-Juana. Jurnal Manajemen Udinus 1(1): 1-12.

40. Wiyono, G. (2011). Merancang Penelitian Bisnis dengan Alat Analisis SPSS 17.0 \& Smart PLS 2.0. Edisi Pertama. Cetakan Pertama. UPP STIM YKPN. Yogyakarta.

41. Zainuddin, P., Riama, L.V., \& Oktarida, A. (2015). Pengaruh Kompetensi dan Motivasi Kerja terhadap Kepuasan Kerja serta Implikasinya pada Kinerja Dosen (Survei pada Perguruan Tinggi Negeri Kota Palembang. Prosiding Sosial, Ekonomi, dan Humaniora $5(1): 1-12$.

42. Zubair, M.Y., \& Chair, S. (2015). Pengaruh Budaya Organisasi, Komitmen Organisasi terhadap Kepuasan Kerja serta Dampaknya terhadap Kinerja Karyawan Bank. Jurnal Riset Manajemen 2(5): 29-38. 